\title{
Influence of treatment with immunosuppressive drugs in mice chronically infected with Trypanosoma cruzi
}

\author{
SONIA G. ANDRADE, AYDANO CARNEIRO FILHO, \\ ANDRÉ J. MAIA DE SOUZA, ELIANITA SUZART DE LIMA \\ AND ZILTON A. ANDRADE \\ Centro de Pesquisas Gonçalo Moniz, Salvador, Bahia, Brazil
}

\begin{abstract}
Received for publication 6 January 1997
\end{abstract}
Accepted for publication 8 September 1997

\begin{abstract}
Summary. Latent Trypanosoma cruzi infection may be reactivated in immunosuppressed individuals, with unusual clinical patterns, such as meningoencephalitis, pseudo neoplastic lesions in the central nervous system, and myocarditis with numerous parasites in the heart muscle. To investigate this problem 68 Swiss mice chronically infected with different strains of $T$. cruzi were treated with different combinations of immunosuppressive drugs (azathioprine, cyclosporine and betamethasone), in such a way as to imitate the situation during post transplantation treatment. Mortality varied from 6 to $25 \%$ in treated mice. There were no deaths in untreated controls. Normal mice have been submitted to the same schedules of immunosuppression as controls of treatment and no deaths were registered during treatment. Chronically infected mice showed significant elevation of total number of leukocytes and lymphocytes in comparison with intact controls; a significant decrease in blood leukocytes and lymphocytes occurred post-treatment in two of the treated experimental groups. Exacerbation of myocarditis and myositis and a high incidence of brain lesions, with focal necrosis, granulomatous lesions and glial proliferation even in the absence of parasites were present in immunosuppressed mice but not in infected controls. Although differing in some aspects from Chagas' disease in immunosuppressed humans, the murine model did show some features that resembled it, especially the peculiar pattern of central nervous system involvement.
\end{abstract}

Keywords: Trypanosoma cruzi, Immunosuppression, azathioprine, cyclosporine, betamethasone.

Acute reactivation of chronic Trypanosoma cruzi infection has occurred in cases of immunosuppression, either therapeutically induced, as during organ transplantation (Stolf et al. 1987; Libow et al. 1991) or AIDS-associated (Ferreira et al. 1991; Rosemberg et al. 1992; Metze \&

Correspondence: Dr. Sonia G. Andrade, Chief of the Experimental Chagas' disease Laboratory, Centro de Pesquisas Gonçalo Moniz - Rua Waldemar Falcão, 121 (Brotas), CEP: 40925001 Salvador, Bahia - Brazil.
Maciel 1993; Rocha et al. 1994). In the former, patients have exhibited severe myocarditis with intracellular parasitism and also subcutaneous nodules with abundant parasites within macrophages. In the later, AIDS patients with the indeterminate form of Chagas' disease have presented parasite-laden meningoencepahlitis and/or pseudo-neoplastic lesions within the central nervous system (Frumkin \& Victoroff, 1990). An isolated T. cruzi pseudo-neoplastic lesion of the brain has been reported 
as early as 1973 but the immunological status of the host had not been determined (Queiroz 1973).

The aim of this study is to investigate whether the peculiar behavior of $T$. cruzi infection in immunosuppressed individuals can be replicated experimentally. Therefore, the evolution of chronic $T$. cruzi infection in mice was investigated, by administering diverse combinations of cylcosporine, azathioprine and corticosteroid drugs in order to simulate as close as possible the situation in transplanted patients.

\section{Materials and methods}

Groups of 100 Swiss mice weighing 15 to $18 \mathrm{~g}$ were infected with one of the following $T$. cruzi strains classified as Type I ( $Y$ and Peruvian) and Type II (21SF) (Andrade, 1966). Inocula were of $4 \times 10^{3}$ trypomastigotes obtained from infected mouse blood. Parasitaemia and mortality were registered in the acute phase; three doses of $50 \mathrm{mg} / \mathrm{kg}$ of Benznidazole were administered on days 9,22 and 23 after inoculation, to avoid high parasitaemia and associated mortality. Survivors from the two groups were used 5 to 6 months after infection: 22 chronically infected with the Peruvian or $Y$ strains and 30 with the $21 \mathrm{SF}$ strain. In addition, 16 mice chronically infected with type III strains (Colombia, Bolivia and Montalvania strains), 3-5 month surviving spontaneously from different groups of laboratory passages of the strains, were also included in this investigation. For the animals infected with Type III strains the inocula varied from $5 \times 10^{4}$ to $3 \times 10^{5}$.

As controls of treatment 35 Swiss normal mice weighing 15 to $18 \mathrm{~g}$ were submitted to treatment with the same schedules as the infected mice, being used 10 mice for each group and one group of 5 intact controls.

\section{Groups of treatment}

For each strain, the chronically infected mice were divided into four sub-groups: $A$, treated with azathioprine (Imuran) and betamethasone (Celestone); B, Treated with cyclosporine (Sandimun) and betamethasone; C, Treated with azathioprine + cyclosporine + betamethasone; D, Infected mice treated with saline solution. Another group of 10 normal mice of the same age were also used as intact controls. The normal mice that has been used as controls of treatment were divided into four sub-groups; E, Treated with azathioprine + betamethasone; F, Treated with betamethasone + cyclosporine; G, Treated with azathioprine
+ betamethasone + cyclosporine: $\mathrm{H}$, Normal (untreated) controls.

\section{Treatment schedules}

The initial schedule was based on that used for the treatment of transplanted patients (Couto, 1995) and applied for the animals infected with Type I and Type III strains. Doses and administration of the drugs were as follows: azathioprine, $2 \mathrm{mg} / \mathrm{kg}$ b.w./day by gavage; betamethasone, $1 \mathrm{mg} / \mathrm{kg}$ b.w./day, intraperitoneally; cyclosporine, 1 st week: $16 \mathrm{mg} / \mathrm{kg}$ b.w./day; 2nd week: $10 \mathrm{mg} / \mathrm{kg}$ b.w./day; 3rd week: $8 \mathrm{mg} / \mathrm{kg}$ b.w./day; 4th week: $6 \mathrm{mg} / \mathrm{kg}$ b.w./day. A higher dose schedule was applied to the mice-infected with the Type II strain, as follows: azathioprine, $10 \mathrm{mg} / \mathrm{kg}$ b.w./day by gavage; betamethasone, $2 \mathrm{mg} / \mathrm{kg}$ b.w./day intraperitoneally; cyclosporine, $30 \mathrm{mg} / \mathrm{kg}$ b.w./day by gavage. The higher doses schedule have been also applied to the controls of treatment. Infected controls were treated with sterile saline, one dose by gavage $(0.7 \mathrm{ml} /$ day $)$ and one intraperitoneally $(0.15 \mathrm{ml} /$ day $)$. Drugs were administered during five consecutive days in a week.

Parasitaemia and mortality were checked before and after treatment. White blood cell counts were also performed before and after treatment for all the animals. Peripheral blood were collected with heparin into plastic vials and examined on an automatic Coulter Counter (T-890). Total number of leucocytes, number of lymphocytes and their percentages were recorded.

\section{Statistical analysis}

Variance test was applied by using the Kruskal-Wallis method for comparing the number of leucocytes and lymphocytes in peripheral blood in normal controls and chronically infected mice from the several experimental groups. Comparison was also performed for leucocytes and lymphocytes from chronically infected mice before and after immunosuppressive treatment. Significance was post-tested by the Dunn's multiple comparison test.

\section{Histopathological study}

Very ill mice were sacrificed 1 to 3 weeks after the beginning of treatment. A few animals survived until 4 weeks of treatment and were sacrificed from 7 to 12 days following treatment. All treated mice, as well as infected and intact ones, were killed under anaesthesia with $5 \%$ hydrocloral solution ( $0.1 \mathrm{ml}$ subcutaneously), after collection of blood from the axillary plexus for white cell count and serological tests (the latter for Type I strains, $Y$ and 
Peruvian only). Sections of heart, skeletal muscle, spleen, liver and brain were fixed in $10 \%$ formalin and paraffin embedded. Five micrometre thick sections were stained with Hematoxylin and Eosin. Cryostat sections of brain tissue embedded in Tissue Tek were submitted to
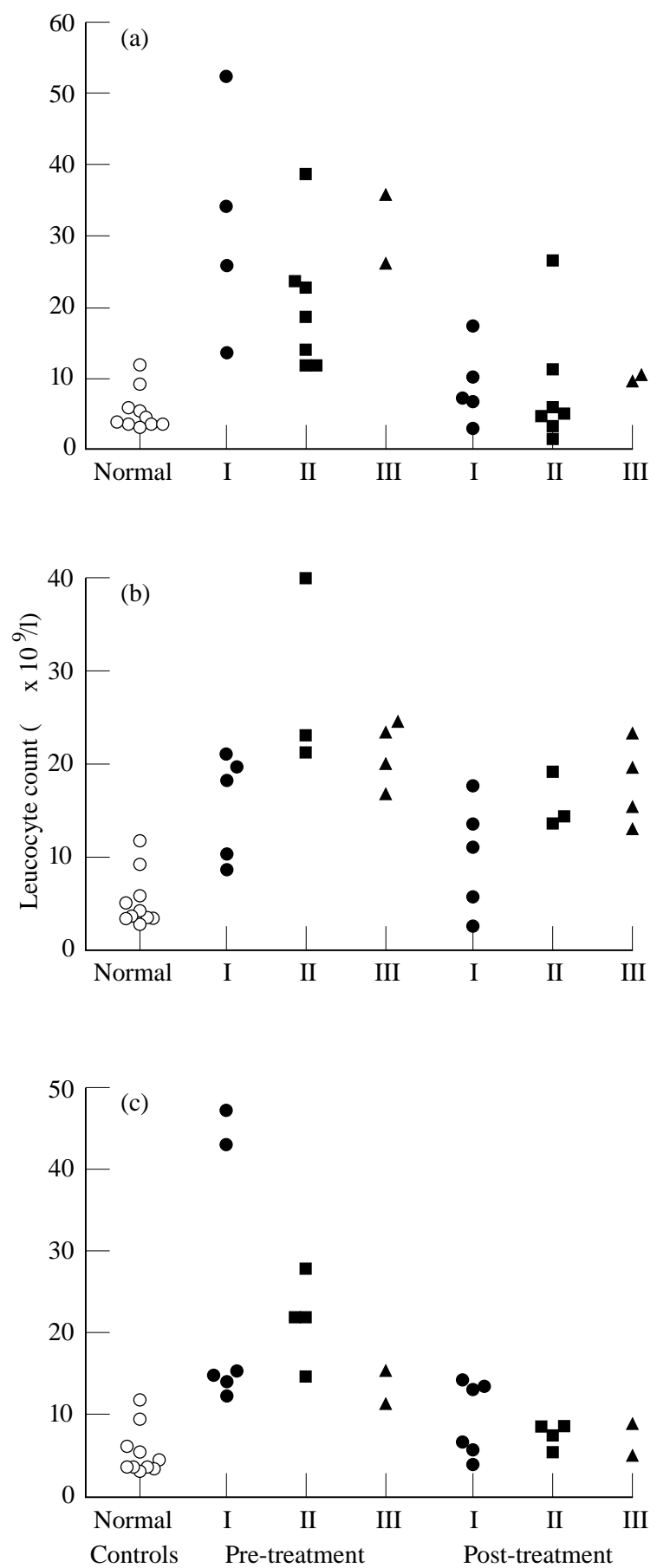

immunohistochemistry to search for parasites. These sections, as well as those obtained from paraffin blocks and previously digested by trypsin, were treated with a monospecific purified anti- $T$. cruzi rabbit serum as primary antibody, in the dilution of 1:640 and 1:1.280 and a goat anti-rabbit IgG conjugated to peroxidase (Sigma) followed by development with diaminobenzidrine.

\section{Serology}

Serum antibodies were examined by indirect immunofluorescence (IIFT) using culture forms of $T$. cruzi as antigens and rabbit-anti- $T$. cruzi monospecific serum as primary antibody in dilutions of $1: 10$ until 1:640. The second label reaction was with goat anti-rabbit IgG conjugated to fluorescein (Sigma).

\section{Results}

Parasitaemia levels during acute infection were evaluated for the strains $\mathrm{Y}$, Peruvian and $21 \mathrm{SF}$ and reproduced the profile for Type I and II strains as previously described (Andrade, 1966). The mortality index during the acute phase was $83 \%$ for the mice infected with the Peruvian strain, $95 \%$ of the $Y$ strain and $81 \%$ for the $21 \mathrm{SF}$ strain. During immunosuppressive treatment in chronically infected animals, the mortality index was of $25 \%$ for Type I strains, $21 \%$ for Type II and $6.2 \%$ for Type III strains. No mortality occurred in the untreated controls as well as in the normal mice treated with the immunosuppressive drugs. In the chronically infected mice parasitaemia was either negative or very low for all the strains. No significant alterations of the parasitaemia curves were observed in the treated animals belonging to the several groups. No differences in mortality were

Figure 1. a, Group A (azathioprine + betamethasone); the total number of leucocytes in peripheral blood of mice chronically infected with $T$. cruz ( $O$ controls, type I, type II, $\Delta$ type III strains) in the pre-treatment phase is significantly higher than in the normal controls; a significant decrease occurred in the post-treatment phase. b), Group B (cyclosporine + betamethasone); the total number of leucocytes in peripheral blood of mice chronically infected with three different strains of $T$. cruzi ( $O$ controls, $\bullet$ type I, $\square$ type II, $\mathbf{\Delta}$ type III): in the pre-treatment phase the levels are significantly higher than in the normal controls; the posttreatment levels are similar to the pre-treatment phase. c, Group C (azathioprine + cyclosporine + betamethasone); the total number of leucocytes in peripheral blood of mice chronically infected with $T$. cruzi (O controls, $\bullet$ type I, $\mathbf{\square}$ type II, $\mathbf{\Delta}$ type III strains). In the pretreatment phase a significantly higher number was seen in comparison with normal controls and a decrease of this number in the post-treatment phase. 
observed between the groups treated with low and high doses of immunosuppressive drugs.

\section{White blood cell count}

The results of the evaluation for the total number of leucocytes on pre-treatment (the day before the initial dose) and post-treatment (the day of sacrifice) animals in each experimental group are shown in Figure 1a-c. Results obtained with the examination of 10 intact controls of the same age, were considered as normal patterns. The total number of leucocytes in the chronically infected mice before treatment, was significantly higher than that obtained in intact controls for the groups A, B and C; statistical analysis by Dunn's comparison test disclosed the levels of significance of $P<0.05$.

Comparison between the total number of leucocytes for each chronically infected mouse in the pre-treatment phase and after treatment with the immunosuppressive drugs showed a decrease that was significant comparing to group A (Figure 1a) treated with azathioprine and betamethasone: $P=0.0317$ (Type I strains), $P=$ 0.0175 (Type II strain) and $P<0.0001$ (Type III strains) and group $C$ (Figure 1c) treated with azathioprine, cyclosporine and betamethasone: $P=0.026$ (Type I strains), $P=0.0286$ (Type II strain) and $P<0.0027$ (Type III strains). Mice from group B (Figure 1b) treated with cyclosporine and betamethasone did not show any significant change in the number of leucocytes after immunosuppressive treatment.

Figure 2 shows that an increased number of
Table 1. Inflammatory lesions in mice infected with $T$. cruzi group $D$, infected controls

\begin{tabular}{lllll}
\hline $\begin{array}{l}\text { Identity } \\
\text { number }\end{array}$ & $\begin{array}{l}\text { Strain } \\
\text { type }\end{array}$ & Heart & $\begin{array}{l}\text { Skeletal } \\
\text { muscle }\end{array}$ & Brain \\
\hline CO-1 & I & + & - & - \\
CO-2 & I & + & - & - \\
CO-5 & II & + & - & - \\
CO-6 & II & + & - & - \\
CO-7 & II & - & - & - \\
CO-8 & II & + & - & - \\
CO-9 & III & + & + & - \\
CO-10 & III & + & $+++^{*}$ & - \\
CO-11 & III & ++ & ++ & - \\
CO-12 & III & ++ & +++ & - \\
CO-13 & III & $++{ }^{*}$ & ++ & + \\
\hline
\end{tabular}

* Presence of amastigotes, + mild,++ moderate,+++ intense

lymphocytes was seen in chronically infected mice, compared with the normal controls for the three experimental groups. These results were statistically significant ( $P<0.01$ for groups $A$ and $B$ and $P<0.05$ for group $C$ ). After treatment, the number of lymphocytes decreased toward the normal level for the groups $\mathrm{A}(P=0.0027)$ and $\mathrm{C}(P=0.0030)$ and persisted above the normal level in the group $B$.

\section{Serological test}

Titres varying from 1:10 to $1: 640$ in the IIFT test were detected in mice chronically infected with Type I strains, regardless of treatment. Negative results were observed in noninfected controls.
Figure 2. Total number of lymphocytes in the three experimental groups $(\diamond$ controls; $\triangle, \Delta$ group $\mathrm{A} ; \mathrm{O}, \bullet$ group $\mathrm{B}$; $\square$, $\square$ group $C$ ), considering both the pretreatment (open symbols) and the posttreatment (closed symbols) phase for each group. Increased number of lymphocytes was seen in the pretreatment phase as compared with normal controls. In the post-treatment phase the number of lymphocytes decreased to normal levels for the groups $A$ and $C$ and persisted above the normal level in the group $B$.

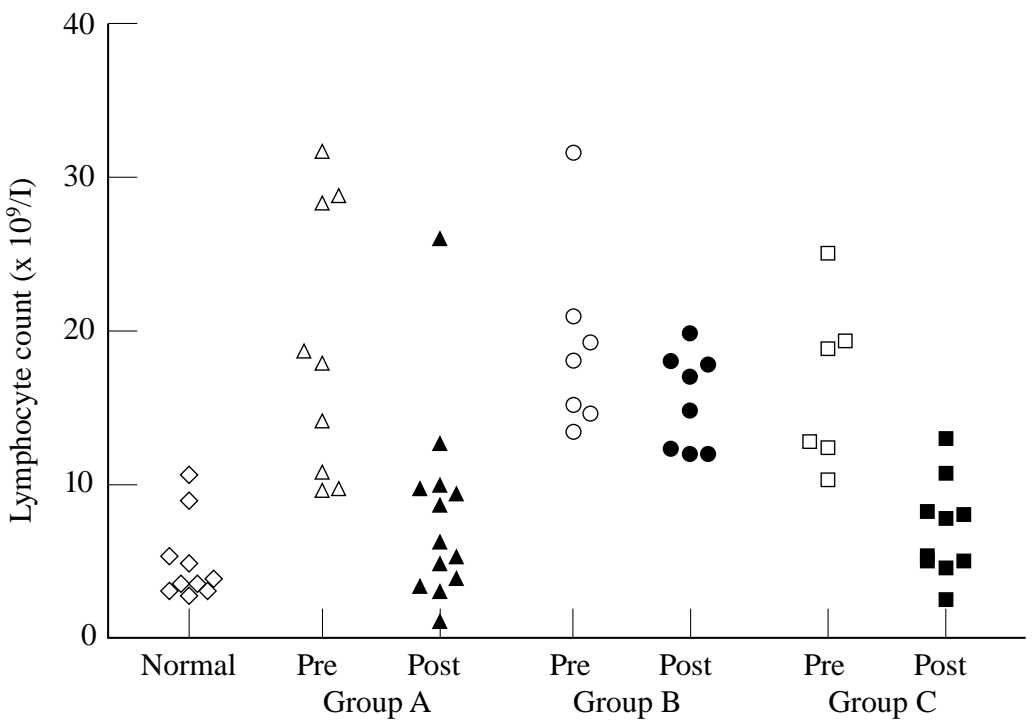

(C) 1997 Blackwell Science Ltd, International Journal of Experimental Pathology, 78, 391-399 
Table 2. Inflammatory lesions in mice infected with $T$. cruzi group A, treated with azathioprine and betamethasone

\begin{tabular}{llllll}
\hline $\begin{array}{l}\text { Identity } \\
\text { number }\end{array}$ & $\begin{array}{l}\text { Strain } \\
\text { type }\end{array}$ & $\begin{array}{l}\text { Treatment } \\
\text { duration }\end{array}$ & Heart & $\begin{array}{l}\text { Skeletal } \\
\text { muscle }\end{array}$ & Brain \\
\hline AB-1 & I & 23d & + & ++ & + \\
AB-2 & I & 32d & + & - & - \\
AB-3 & I & 32d & + & - & - \\
AB-4 & I & 35d & ++ & ++ & - \\
AB-5 & I & 35d & + & + & ++ \\
AB-8 & II & $9 d$ & + & + & + \\
AB-9 & II & 7d & + & - & - \\
AB-10 & II & 7d & + & + & - \\
AB-11 & II & $9 d$ & + & - & + \\
AB-12 & II & 7d & + & - & + \\
AB-13 & II & 28d & + & - & + \\
AB-14 & III & 21d & + & + & ++ \\
AB-15 & III & 21d & + & $+{ }^{*}$ & + \\
AB-16 & III & 21d & ++ & $+++{ }^{*}$ & - \\
\hline
\end{tabular}

* Presence of amastigotes. + mild,++ moderate,+++ intense.

\section{Histopathological study}

Infected controls. Mild (+) focal mononuclear infiltration of the heart, in the absence of parasites in mice chronically infected with Type I or Type II strains (Table 1).
Table 3. Inflammatory lesions in mice infected with $T$. cruzi group $B$, treated with cyclosporin and betamethasone

\begin{tabular}{llllll}
\hline $\begin{array}{l}\text { Identity } \\
\text { number }\end{array}$ & $\begin{array}{l}\text { Strain } \\
\text { type }\end{array}$ & $\begin{array}{l}\text { Treatment } \\
\text { duration }\end{array}$ & Heart & $\begin{array}{l}\text { Skeletal } \\
\text { muscle }\end{array}$ & Brain \\
\hline CB-1 & I & 23d & + & - & + \\
CB-2 & I & 32d & + & ++ & - \\
CB-3 & I & 32d & + & - & + \\
CB-4 & I & 35d & + & + & - \\
CB-7 & II & $9 \mathrm{~d}$ & + & + & ++ \\
CB-8 & II & $9 \mathrm{~d}$ & + & - & - \\
CB-9 & II & 17d & ++ & - & - \\
CB-10 & III & 28d & + & - & + \\
CB-11 & III & 28d & ++ & ++ & - \\
CB-12 & III & 28d & + & + & - \\
CB-13 & III & 28d & + & + & - \\
\hline
\end{tabular}

+ mild,++ moderate,+++ intense

Those infected with Type III strains showed a more intense inflammatory reaction in the myocardium and skeletal muscles, which varied from moderate $(++)$ to marked $(+++)$ and was accompanied by interstitial edema and mild matrix thickening and the eventual presence of intracellular amastigotes. In the brain, focal
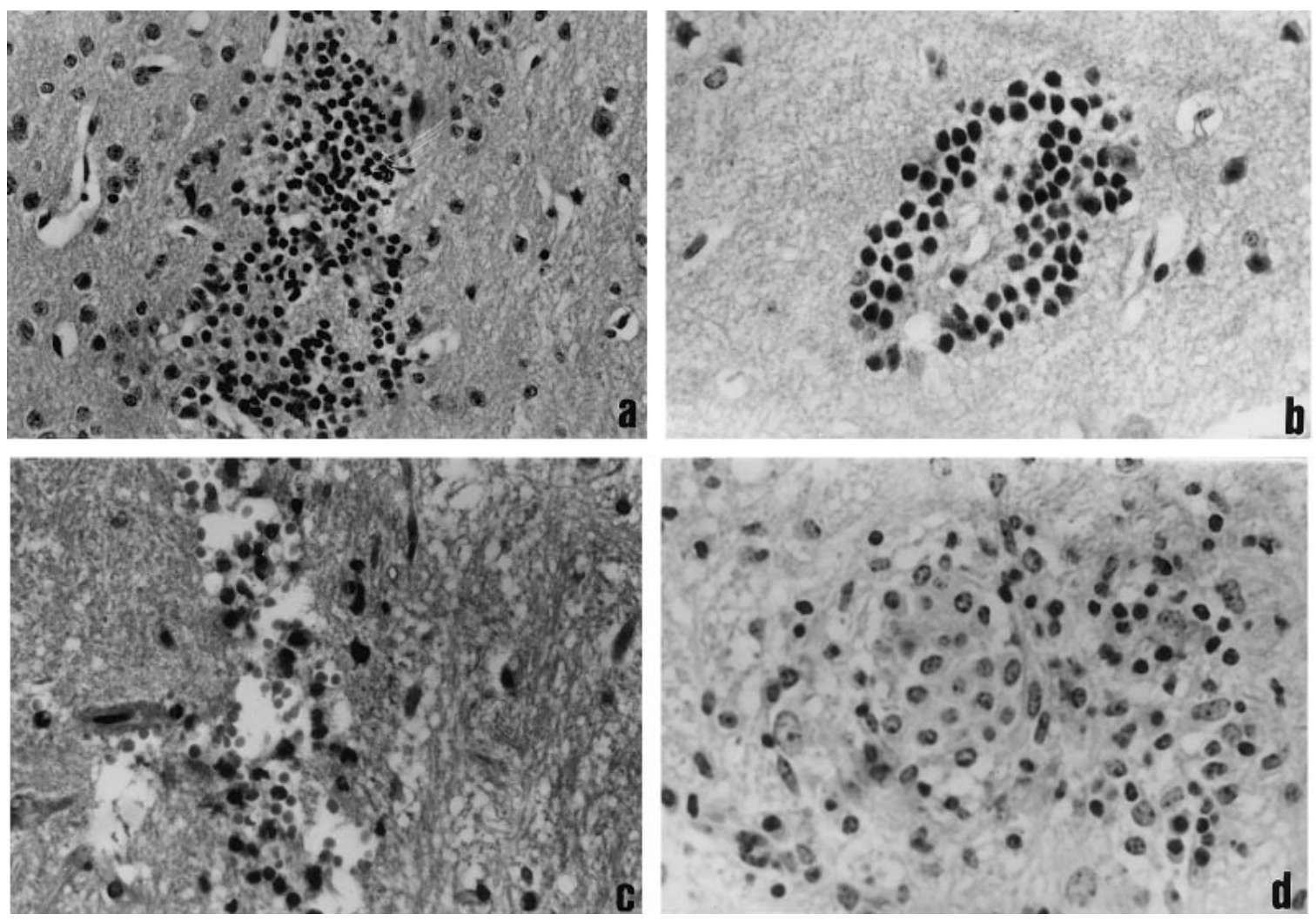

Figure 3. Brain lesions in mice chronically infected with $T$. cruziand submitted to immunosuppressive treatment. a, diffuse lymphocytic infiltration and glial cells proliferation; $b$, lymphocytic perivascular cuffing; $c$, softening area of the brain with hemorrage and mononuclear infiltration; d, granulomatous reaction with macrophage-like cells, lymphocytes and glial cells proliferation. H\& E, 250×. 

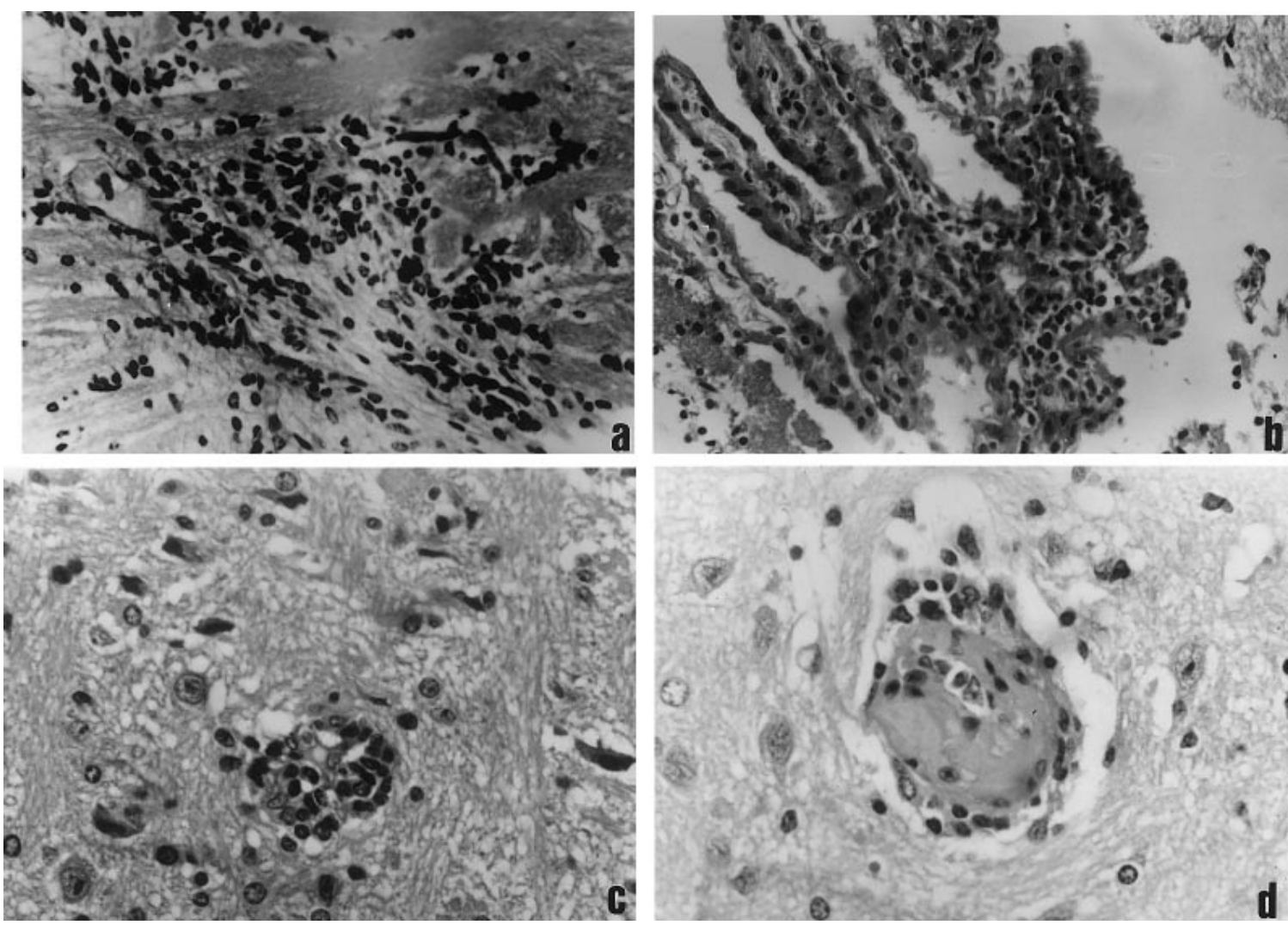

Figure 4. Lesions in the brain of mice chronically infected with T. cruzi treated with immunosuppressive drugs. a, peri-ependimal space showing mononuclear infiltration and glial cells proliferation; b, lymphocytic infiltration of the choroid plexus; $c$, dense perivascular mononuclear infiltration and nervous tissue vacuolization; $d$, necrosis, hyalination and mononuclear cells infiltration of brain arteriole. $H \& E, 250 x$.

perivascular mononuclear infiltration was present in the meninges and, as a mild diffuse mononuclear infiltration, at the axis of the choroid plexus. No involvement of the brain substance itself was detected.

Table 4. Inflammatory lesions in mice infected with $T$. cruzi group C, treated with azathioprine + cyclosporine + betamethasone

\begin{tabular}{llllll}
\hline $\begin{array}{l}\text { Identity } \\
\text { number }\end{array}$ & $\begin{array}{l}\text { Strain } \\
\text { type }\end{array}$ & $\begin{array}{l}\text { Treatment } \\
\text { duration }\end{array}$ & Heart & $\begin{array}{l}\text { Skeletal } \\
\text { muscle }\end{array}$ & Brain \\
\hline ACB-1 & I & 23d & + & + & + \\
ACB-2 & I & 32d & + & + & + \\
ACB-3 & I & 32d & ++ & ++ & ++ \\
ACB-4 & I & 32d & ++ & $++{ }^{*}$ & - \\
ACB-5 & I & 35d & + & - & - \\
ACB-6 & I & 35d & + & - & - \\
ACB-7 & II & $7 d$ & + & - & + \\
ACB-8 & II & 16d & - & - & + \\
ACB-9 & III & 7d & + & $+{ }^{*}$ & - \\
AXB-10 & III & 22d & + & $++{ }^{*}$ & + \\
ACB-11 & III & 22d & ++ & $+{ }^{*}$ & + \\
\hline
\end{tabular}

*Presence of amastigotes. + mild,++ moderate,+++ intense.
Infected mice treated with immunosuppressive drugs. Group A, animals treated with azathioprine and betamethasone (Table 2); brain lesions were present in 8/14 mice. These consisted of focal and diffuse proliferation of glial cells and lymphocytic infiltration (Figure $3 a$ and b) with necrosis of cerebral tissues (Figure 3c) and granulomatous reaction with macrophage-like cells (Figure 3d). In some cases mononuclear infiltration occurred in the periependimal space (Figure 4a) and in the choroid plexus (Figure 4b). Meningeal involvement with dense mononuclear perivascular infiltration was present. Vascular alterations with periarteriolar inflammatory infiltration and arteriolar hyalinization were seen (Figures 4c,d). Immunohistochemical labelling with peroxidase did not reveal $T$. cruziamastigotes, or antigenic-related material. Infection with Type I and II strains revealed mild $(+)$ to moderate $(++)$ focal inflammatory lesions in the myocardium and skeletal muscles as seen in the untreated controls (Figures 5a,b). With Type III strains lesions were similar to those seen in untreated controls. 

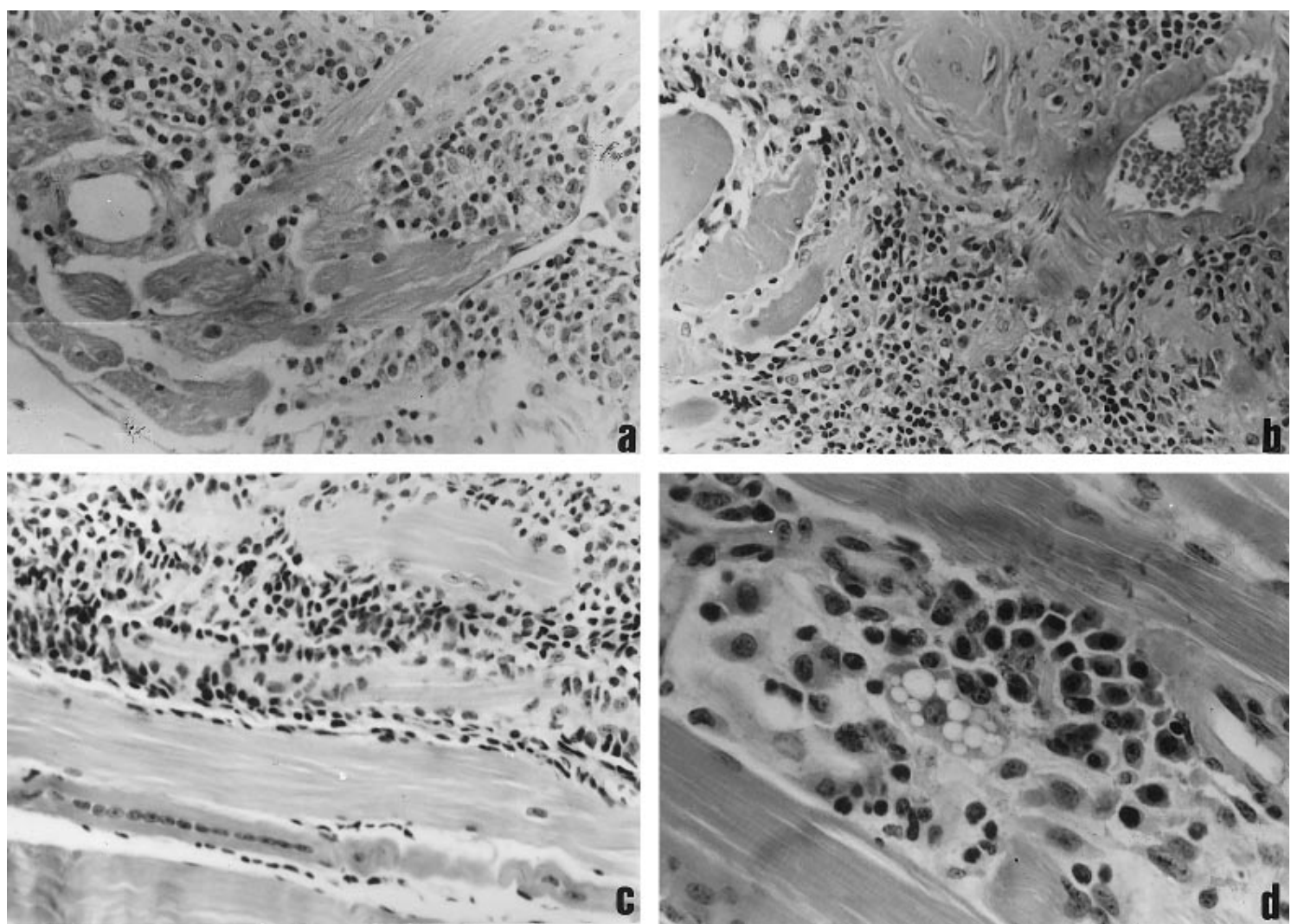

Figure 5. Focal infiltration with macrophages and lymphocytes of the myocardium in mice chronically infected with $T$. cruzi. a, in the pre-treatment phase; $b$, treated with azathioprine and betamethasone; $c$, skeletal muscle with dense mononuclear cells infiltration and fibroblasts in chronically infected mouse treated with cyclosporine and betamethasone; $\mathrm{d}$, focal interstitial infiltration of skeletal muscle with macrophages, lymphocytes and plasmocytes in mouse chronically infected and treated with azathioprine + cyclosporine + betamethasone. H\&E, 250x.

Group B, animals treated with cyclosporine and betamethasone (Table 3); lesions were similar to those observed in the Group $A$ in the heart and skeletal muscles of mice infected with Types I and II strains (Figure 5c). With Type III strains, lesions of the skeletal muscle were less intense than those observed in group A. Cerebral lesions as described for Group A were present in 4/11 mice (Table 3). No parasites were detected by immunohistochemistry.

Group C, animals treated with azathioprine, cyclosporine and betamethasone (Table 4); showed mononuclear infiltration of the myocardium and skeletal muscles with the presence of plasmocytes (Figure 5c). Focal mononuclear infiltration of the cerebral tissue occurred in $7 / 11$ mice but immunohistochemical staining with peroxidase was negative for parasites within these foci. Normal controls did not show any histopathological alterations of the several examined organs and tissues.
Controls of treatment. Group E, (azathioprine and betamethasone); heart with normal structure showing in some cases mild and focal perivascular mononuclear infiltration and edema; skeletal muscle and brain without histological alterations. Group F, (cyclosporine and betamethasone); heart with normal structure except for the presence of mild and focal mononuclear infiltration and small areas of myocytolisis of the myocardium in two cases (Figure 6a); skeletal muscle with normal structure; in the brain, focal area of peri-ependimal mononuclear cells infiltration was seen in one case, without parenchimal infiltration. Group G, (azathioprine + betamethasone + cyclosporine); normal structure of the heart with mild mononuclear infiltration and small focal areas of myocytolisis of the atrial myocardium in two cases; normal skeletal muscle structure; focal mononuclear cells infiltration in the periependimal tissue in one case (Figure 6c). 

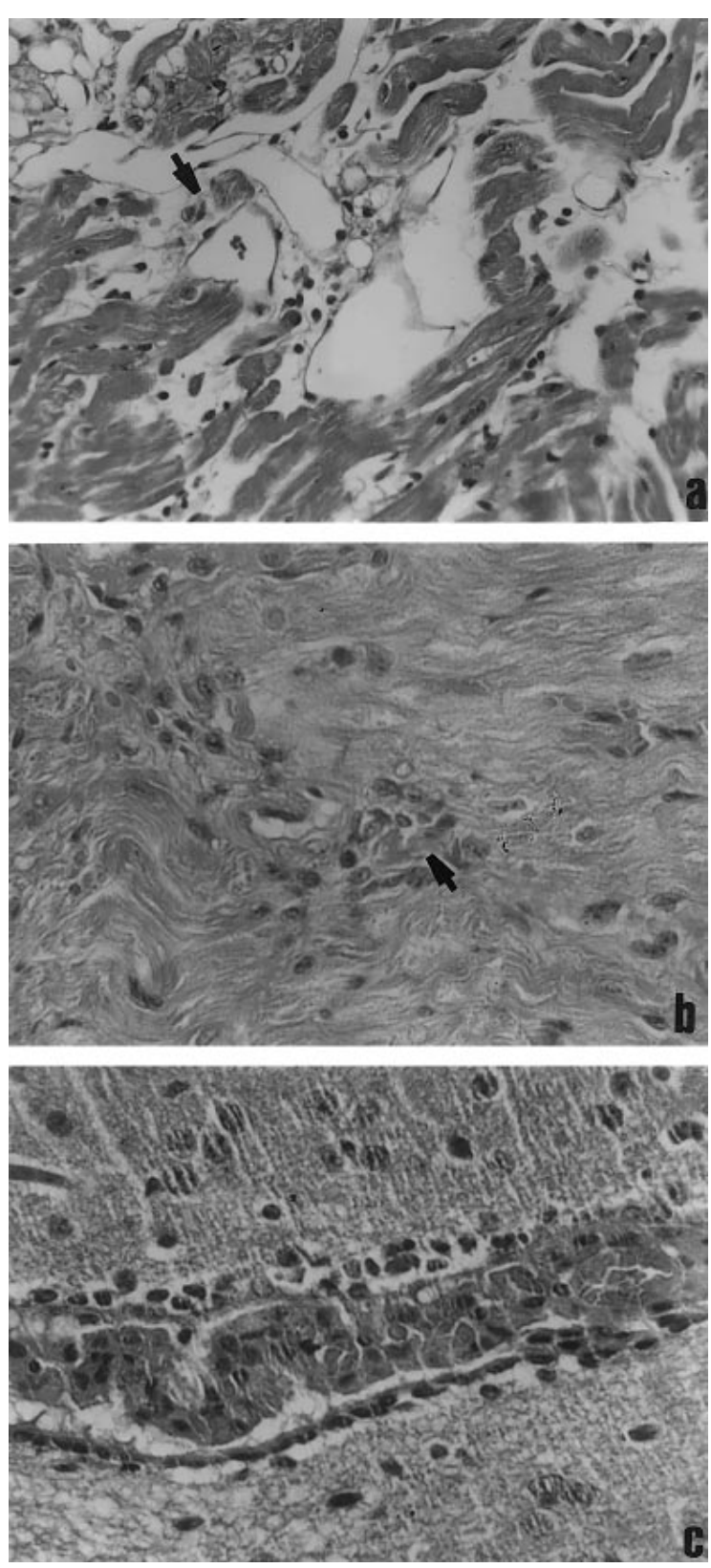

Figure 6. Histopathological aspects in mice used as controls of treatment. a, group $\mathrm{F}$ (cyclosporine and betamethasone) atrial myocardium showing interstitial oedema, mild mononuclear infiltration and focal myocytolisis (arrows); b, group G (azathioprine + betamethasone + cyclosporine) myocardium with focal area of myocytolisis (arrow) and focal mononuclear infiltration; c, group G (azathioprine + betamethasone + cyclosporine) brain: focal peri-ependimal mononuclear cells infiltration. $\mathrm{H} \& \mathrm{E}, 250 \times$.

\section{Discussion}

Experimental studies in mice have demonstrated that immunosuppressive treatment made during the acute phase of $T$. cruzi infection induces aggravation of the infection with enhancement of parasite multiplication and high mortality (Andrade \& Andrade 1996a, b; Andrade \& Macedo 1973). During chronic infection (Brener \& Chiari 1971) immunosuppression with cyclophosphamide resulted in reactivation of infection, while azathioprine administration failed to affect the course of infection. Other studies have shown that both cyclophosphamide (Maghalhães \& Andrade 1995), and cyclosporine (Amato Neto et al. 1986) may fail to modify the course of infection, except for turning a negative parasitaemia into a low grade positive one.

In the present study mice with chronic $T$. cruzi infection exhibited, when under immunosuppessive therapy, high mortality and leukopenia with lymphopenia. This was true for the animals treated with a combination of azathioprine and betamethasone and for those treated with cyclosporine, azathioprine and betamethasone, but the group with cyclosporine and betameathasone maintained the same pre-treatment levels of peripheral leucocytes and lymphocytes. It seems that azathioprine is essential for leucocyte depletion. Considering that each drug used has different mechanisms of action it is very difficult to interpret the different responses obtained with combined treatment. Cyclophosphamide affects humoural immunity, azathioprine is a potent cellular immunity suppressor; cyclosporine interferes with the production of IL2 by T lymphocytes and the corticoids block the liberation of IL1, IL2 and INF $\gamma$. In normal mice, treatment with the immunosuppressor drugs here used did not elicit the development of lesions that could be compared with those determined by $T$. cruzi infection, being limited to focal mononuclear infiltrations and in a few cases, focal areas of cardiac myocitolisis. According to Couto (1995) there are no evidences that the several immunosuppressor drugs used in different combinations in cardiac transplant, such as cyclosporine, azathioprine and corticosteroids, can have any influence on the clinical course or survival rates on cases of chronic lymphocytic myocarditis, although these drugs may be active in acute cases.

It is interesting that the animals receiving immunosuppressive drugs did not show reactivation during chronic $T$. cruzi infection, a very low parasitemia and low grade tissue parasitism being maintained during the course of treatment and thereafter. However, there was a clear influence of the treatment on the development of cerebral lesions; while untreated chronically infected mice 
showed only focal infiltrates in the meninges and choroid plexus, all treated animals disclosed a high incidence of focal inflammatory brain lesions. In the absence of parasites, pathogenesis for these focal inflammatory lesions appears complex. A paradoxical immunological hypersensitivity reaction cannot be ruled out, since granulomatous reactions, sometimes centered by necrosis, are considered hallmark of delayed type cellular immunity. In human cases of immunodeficiency, being it drug induced or acquired (AIDS), the reactivation of $T$. cruzi infection is accompanied by parasite-laden skin lesions, myocarditis and encephalitis, without a concomitant increase of parasites in peripheral blood (Metze \& Maciel 1993; Ferreira et al. 1991). In the present study the cardiac lesions were not inhibited and were even increased under immunosuppressive treatment and these results are comparable to those obtained by Higuchi et al. (1990) in the study of endocardial biopsies of patients with dilated myocardiopathy, submitted to immunosuppressive treatment. Our results are comparable to those obtained with the use of low doses of cyclophosphamide in dogs (Andrade et al. (1987), in which the interference with the immunological network precipitated the development of lesions of delayed hypersensitivity in the heart of dogs treated during the indeterminate form of Chagas' disease. Now, the immunosuppressive drugs determined a slight enhancement of myocardial lesions in mice and also the appearance of significant brain lesions in all the experimental groups of immunosuppression. Although the picture seen in our immunosuppressed mice differs in many details from that observed in $T$. cruzi infected man with immunodeficiency syndromes, the murine model appears nonetheless useful for further studies on the mechanisms involved on the pathogenesis of the peculiar behavior of the central nervous system lesions found in patients.

\section{Acknowledgments}

Thanks are due to Mariza Soares de Paixão, Chief of the Clinical Analysis Sector of the LACEN (Central Laboratory of Bahia State) for the haematological examination and to Dr. Manoel Barral Neto for the statistical analysis.

\section{References}

Amato Neto V., Moreira A.A.B.M, Campos R., Duarte M.I.S., PInTo P.S.L. \& Santana E.J. (1986) Observação experimental e preliminar sobre a eventual influência da ciclosporina na infecção crônica de camundongos pelo Trypanosoma cruzi. Rev. Hosp. Clin. Fac. Med. S. Paulo 41, 219-221.

AndRADE S.G. (1966) Caracterização de cepas do Trypanosoma cruzi isoladas no Reconcavo Bahiano. Rev. Patol. Trop. 3, 65-121.

Andrade S.G. \& Andrade Z.A. (1966a) Doença de Chagas e alterações neuronais do plexo de Auerbach. Rev. Inst. Med. Trop. São Paulo 8, 219-224.

AndRADE S.G. \& AndRADe A.A. (1966b) Estudo histopatológico comparativo das lesões produzidas por duas cepas do Trypansoma cruzi. O Hospital 70, 1267-1278.

AndRAde S.G. \& MAcedo V. (1973) Tratamento combinado da doença de Chagas com Bayer 2502 e corticoide (estudo experimental e clínico). Rev. Inst. Med. Trop. São Paulo 15, 421-430.

Andrade Z.A., Andrade S.G. \& Sadigurski M. (1978) Enhancement of chronic Trypansoma cruzi myocarditis in dogs treated with low doses of Cyclophosphamide. Amer. J. Pathol. 127, 467-473.

Brener Z. \& ChiARI E. (1971) The effects of some immunosupressive agents in experimental chronic Chagas' disease. Trans. Roy. Soc. Trop. Med. Hyg. 65, 628-636.

Couto A.A. (1995) Imunosupressores em Cardiologia. Arq Bras. Med. 69, 69-72.

Ferreira M.S., Ishioka S.A., Rocha A., Silva A.M., Ferreira R.C., OlivieR W. \& Tostes JR.S. (1991) Acute fatal Trypanosoma cruzi meningoencephalitis in a human immunodeficiency virus-positive hemophiliac patient. Amer. J. Trop. Med. Hyg. 45, 723-727.

Higuchi M.L., Camargo P.R., Aiello V.D., Mazzieri R., Snitcowsky R., Fiorelli A., Ebaid M. \& Pileggi F. (1990) Reposta histolólogica do miocardio a diferentes esquemas imunossupressores em pacientes com cardiomiopatia dilatada e diagnóstico de miocardite à biópsia endomiocardica. Arq. Bras. Cardiol. 54, 319-322.

Libow L.F., Beltrani V.P., Silvers D.N. \& Grossman M.E. (1991) Post-cardiac transplant reactivation of Chagas' disease diagnosed by skin biopsy. Cutis 48, 37-40.

Magalhäes J.B. \& ANDRAde S.G. (1994) Investigation on the possibility of spontaneous cure of mice infected with different strains of Trypanosoma cruzi. Rev. Inst. Med. Trop. São Paulo 35, 481-484.

Metze K. \& Maciel JR. JA. (1993) AIDS and Chagas' disease. Neurology 43, 447-448.

Quelroz A.C. (1973) Tumor-like lesion of the brain caused by Trypanosoma cruzi. Am. J. Trop. Med. Hyg. 22, 473476.

Rocha A., Menezes A.C.O., Silva A.M., Ferreira M.S., Nishioka S.A., Burgarelli M.K.N., Almeida E., Turcato JR. G., Metze K. \& Lopes E.R. (1994) Pathology of patients with Chagas' disease and acquired immunodeficiency syndrome. Am. J. Trop. Med. Hyg. 50, 261268.

Stolf N.A., Bocch E. \& AuleR J.O.C. (1987) Heart transplantation in patients with Chagas' disease cardiomyopathy. J. Heart Transplant. 6, 307-312. 